\title{
The Phenomenon of Qalqala in Qur'ān Recitation*
}

\author{
Prof. Dr. Abbas Jawdat Rahim \\ Maryam Falih Ahmad \\ Department of English \\ Al-Kitab University College \\ Kirkuk, Iraq
}

\begin{abstract}
This study investigates the phenomenon of qalqala, a feature unique to Qur'ān recitation. It aims at analyzing the sound accompanying the qalqala sounds $[q, t, b, d\}, d]$ acoustically to see whether or not this sound has a vowel-like articulation. Therefore, an acoustic analysis has been conducted to the sound accompanying the qalqala sound together with the preceding and following vowels to give their acoustic features such as the amplitude (i.e. the intensity), the formant frequencies (F1 and F2) and the recurrence of waves at regular intervals. The main conclusions of the present research are: (a) the sound accompanying the qalqala sound is a vowel-like articulation (b) this vowel, in most cases, tends to be /o/ and (c) the phenomenon of qalqala is of two levels, minimum and maximum.
\end{abstract}

Keywords: qalqala, recitation, Qur'an, acoustic analysis, phonemic status.

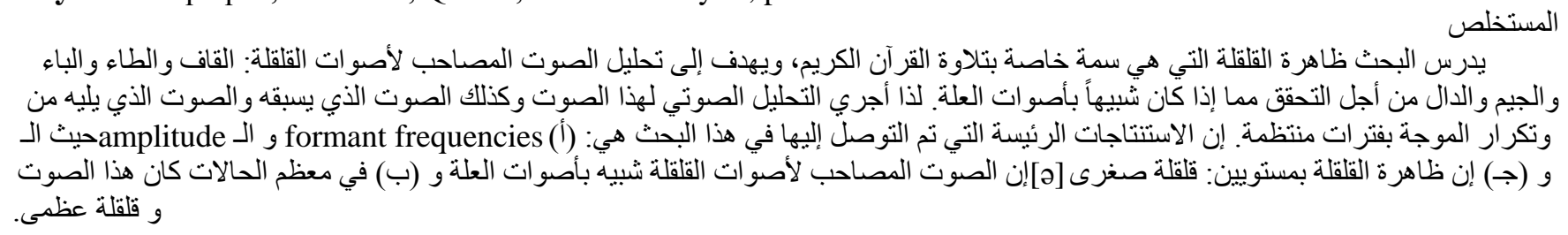

\section{Introduction}

The phenomenon of qalqala in Qur'ān recitation violates the natural human tendency for economy of muscular effort, since it is much more difficult to produce a sound like [b] with qalqala than producing a simple non-muqalqal [b]. It is realized as a sound that accompanies the release phase of the five Arabic stop sounds of qalqala[q, t, b, ds, d]. Making qalqala with these sounds prevents the sound of qalqala from becoming like the following sound in somefeature(s), as in the sound [b] in ['jabtari:] becoming *['japtari:], or avoids assimilating [d] to the following [ș] in the phrase ['laqadșar'rafna:] tomake it sound as *['laqașșar'rafna:].Both of these cases which result from not making qalqala violate the rules of recitation.

Many studies have described the sounds of qalqala from the articulatory point of view and described the sound that accompanies the qalqala sound as a sound that resultsfrom the separation of the contact between the articulators. Old Arab grammarians like "Sỉbawayhi describes qalqala sounds as the musharraba, i.e. accompanied by something not of its nature, viz. a slight movement or șuwayt"(Bishr, 2000: 384).Contemporary Arab grammarians view qalqala as "the strength of turbulence in the place of articulation of the sound when uttered in its non-vocalized form resulting in strong strain"(Al-Ghawthāniyy, 2011: 107 and Zalat,, 2005: 62).On the other hand, non-Arab scientists define qalqala as an insertion of a schwa after qalqala sounds (e.g. Denny, 1989: 19 and Nelson, 2001: 22f). Arab scholars differ in their viewpoints about qalqala types (i.e. levels). Some believe that it is of two types according to the position of the sound in the word ignoring the geminate/non-geminate distinction of the non-vocalized form in word-final position (e.g. Arbāwiyy, 2004: 40and Swayyid, 2011: 189). Others divide it into three types; the third being the geminated pausal form of qalqala sound in final position which is considered as the strongest (e.g. Al-Harbiyy, 2006: 13and Sulaymān, 1988: 57).This study describes the phenomenon of qalqala acoustically by means of adobe audition 2.0. An acoustic analysis has been conducted to measure the acoustic features of qalqala sounds such as the amplitude (i.e. intensity), the formant frequencies (F1 and F2)and the recurrence of waves at regular intervals.

\section{Statement of the problem}

The present research tries to investigate the phenomenon of qalqala instrumentally in order to arrive at the instrumentally-evidenced phonetic facts about this unique phonetic phenomenon which, to the best of our knowledge, has not been studied instrumentally before. 


\section{Aim of the study}

This study aims to present an acoustic description of the sound accompanying the qalqala sound by measuring its intensity and formant structure and comparing it with that of the vowels that precede and follow it in order to determine the phonetic and phonemic identity of the sound accompanying the qalqala sound.

\section{Procedures}

The procedures to be followed in this research are as follows:

a. Examining the sound accompanying the qalqala sound acoustically to show its waveform and formant structure; this will be done for each of the four Qur'ān reciters ${ }^{(1)}$.

b. Working out the phonemic status of the sound accompanying the qalqala sound.

\section{Hypotheses}

a. The sound accompanying the qalqala sound in the post-release phaseis realized as a vowel-like articulation.

b. The vowel occurring as a result of the phenomenon of qalqala is mostly [ə].

c. The phenomenon of qalqala in reciting the Glorious Qur'àn is of two levels, minimum and maximum.

\section{Acoustic Investigation of the Qalqala Sounds}

In the acoustic investigation of the qalqala sounds, three things have been accounted for: amplitude, formant frequency and waveform repetition. These have been worked out for each of the four reciters.

\subsection{Amplitude Analysis}

Ladefoged (1993: 163) states that "the intensity is proportional to the average size, or amplitude, of the variations in air pressure...measured in decibels (abbreviated as $\mathrm{dB}$ ) relative to the amplitude of some other sounds". AlGhāmidiyy(2000: 105) defines amplitude as the amount of sound intensity which is measured by decibel. The amplitude of the sound that accompanies the qalqala sound is calculated by taking the summation of ten peaks of this sound and dividing the number by ten to give the mean value of the intensity of this sound and prove that this sound is a vowel-like articulation.

\subsubsection{Sa'ad Al-Ghāmidiyy}

In Al-Ghāmidiyy's performance, analysis of the post-release phase of the qalqala sounds [q, ț, b, ḑ, d] in word-medial position shows that the sounds accompanying [q]in ['Puq?simu] ${ }^{(2)}$, [ț] in [?aț?'Yamahum], [b] in ['șab?ri], [ḑ] in ['jads? Sal] and [d] in ['ṣad?rak ${ }^{(3)}$ have amplitudes of $+12 \mathrm{~dB},+12 \mathrm{~dB},+10 \mathrm{~dB},+8 \mathrm{~dB}$ and $+14 \mathrm{~dB}$, respectively (see Figure

$1)$.

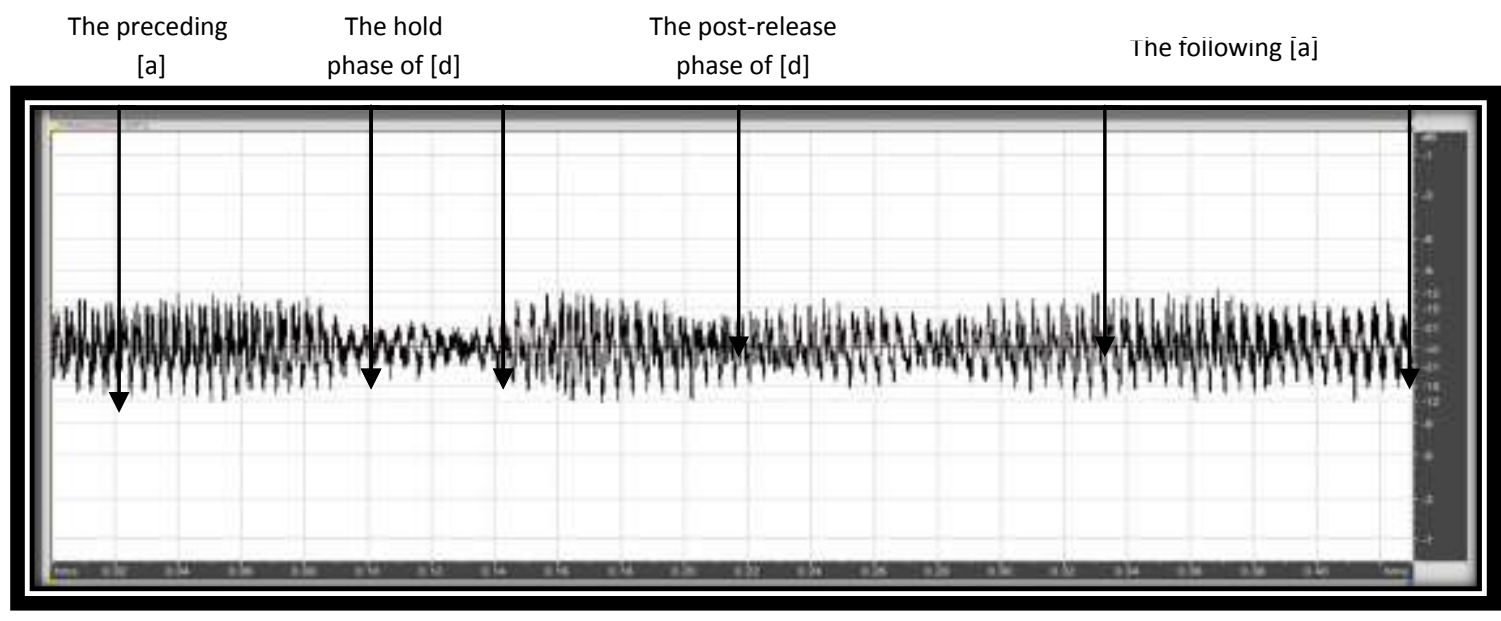

Figure 1: Waveform of the preceding [a], the sound accompanying [d] and the following [a] in ['ṣad?rak] for AlGhāmidiyy.

\footnotetext{
${ }^{(1)}$ The four reciters are: Sa'ad Al-Ghāmidiyy of Saudi Arabia, Muћammad Șiddīq Al-Manshāwiyy of Egypt, Abdul-HādilKanākiriyy of Syria and Ni'mat Al-Hassān of Iraq.

(2)The mark (?) indicates the sound accompanying the qalqala sound before knowing its identity.

${ }^{(3)}$ These words will be the basis of analysis for word-medial qalqala when accounting for the other reciters, so they will not be repeated. 
In word-final position, the sounds accompanying [q] in [?is'tab?raq?], [ț] in ['lu:ț?], [b] in ['waqab?], [ḑ]in ['harads?], [d] in ['kabad?] and the geminated [q] in ['haqq?] ${ }^{(4)}$ have amplitudes of $+12 \mathrm{~dB},+12 \mathrm{~dB},+14 \mathrm{~dB},+8 \mathrm{~dB},+14 \mathrm{~dB}$ and $+13 \mathrm{~dB}$, respectively( see Figure 2).

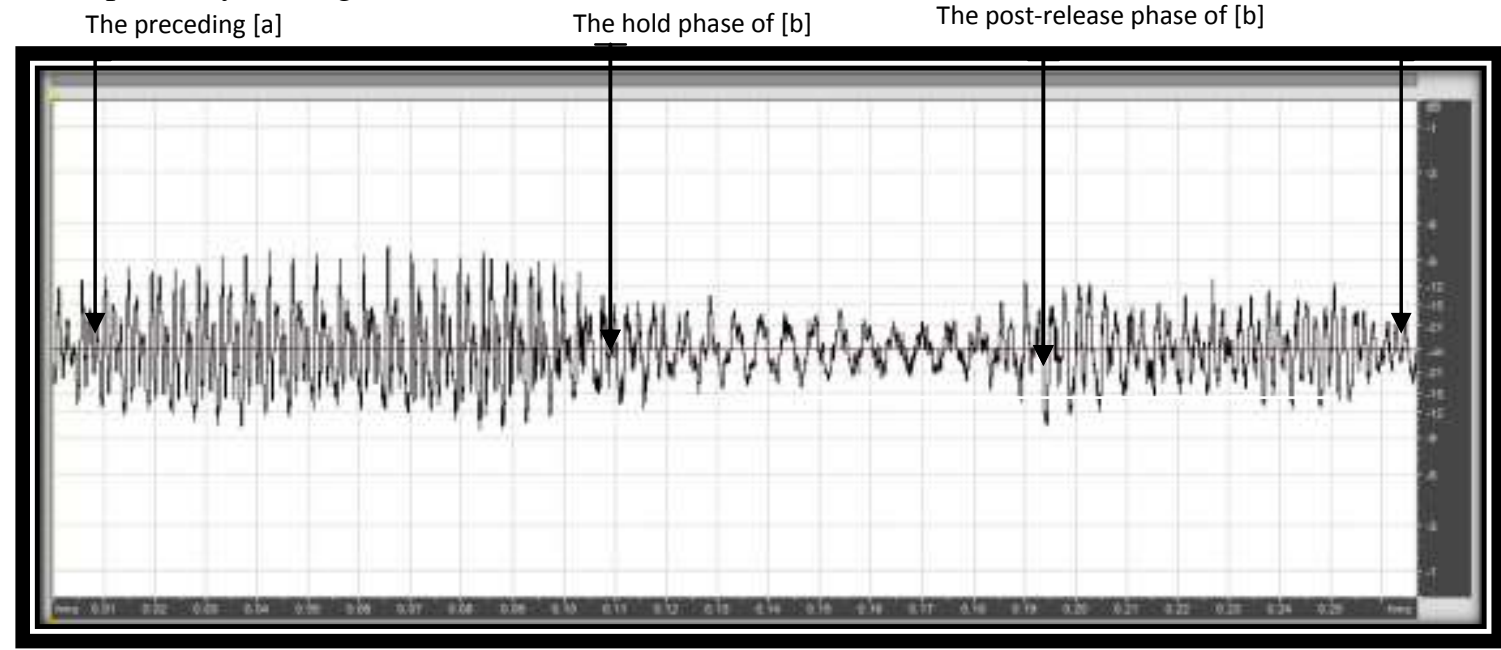

Figure 2: Waveform of the preceding [a] and the sound accompanying [b] in ['waqab?] for Al-Ghāmidiyy.

\subsubsection{MuhammadṢiddīq Al-Manshāwiyy}

In Al-Manshāwiyy'sperformance, analysis of the post-release phase of the qalqala sounds [q, ț, b, dz, d] in word-medial position shows that the sounds accompanying [q], [t]], [b], [d] and [d] have amplitudes of $+17 \mathrm{~dB},+12 \mathrm{~dB},+15 \mathrm{~dB}$, $+10 \mathrm{~dB}$ and $+13 \mathrm{~dB}$, respectively (see Figure 3 ).

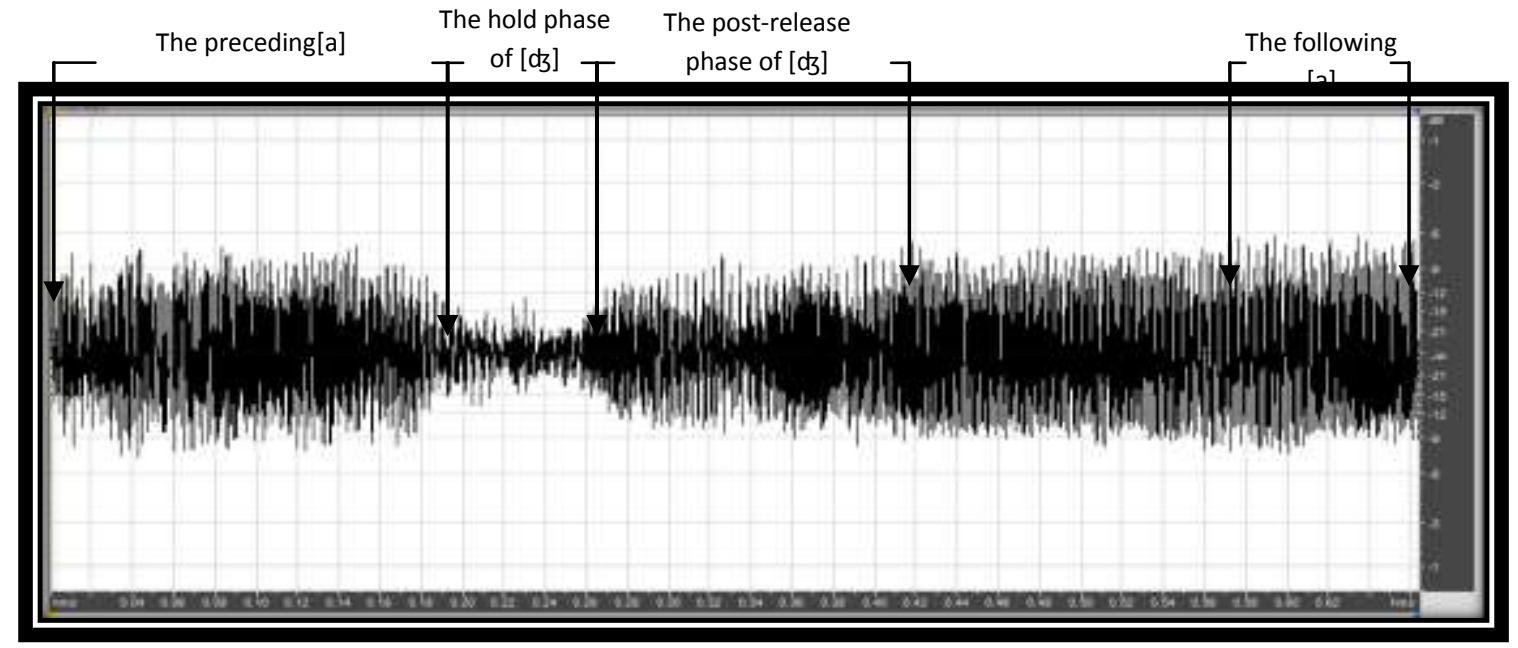

Figure 3: Waveform of the preceding [a], the sound accompanying [d] and the following [a] in ['jadz? $9 a 1]$ for AlManshāwiyy.

In word-final position, the sounds accompanying [q], [t], [b], [d] , [d]and the geminated [q] have amplitudes of $+21 \mathrm{~dB}$, $+16 \mathrm{~dB},+14 \mathrm{~dB},+19 \mathrm{~dB},+18 \mathrm{~dB}$ and $+13 \mathrm{~dB}$, respectively (see Figure 4 ).

\footnotetext{
${ }^{(4)}$ These words will be the basis of analysis for word-final qalqala when dealing with the other reciters, so they will not be repeated.
} 


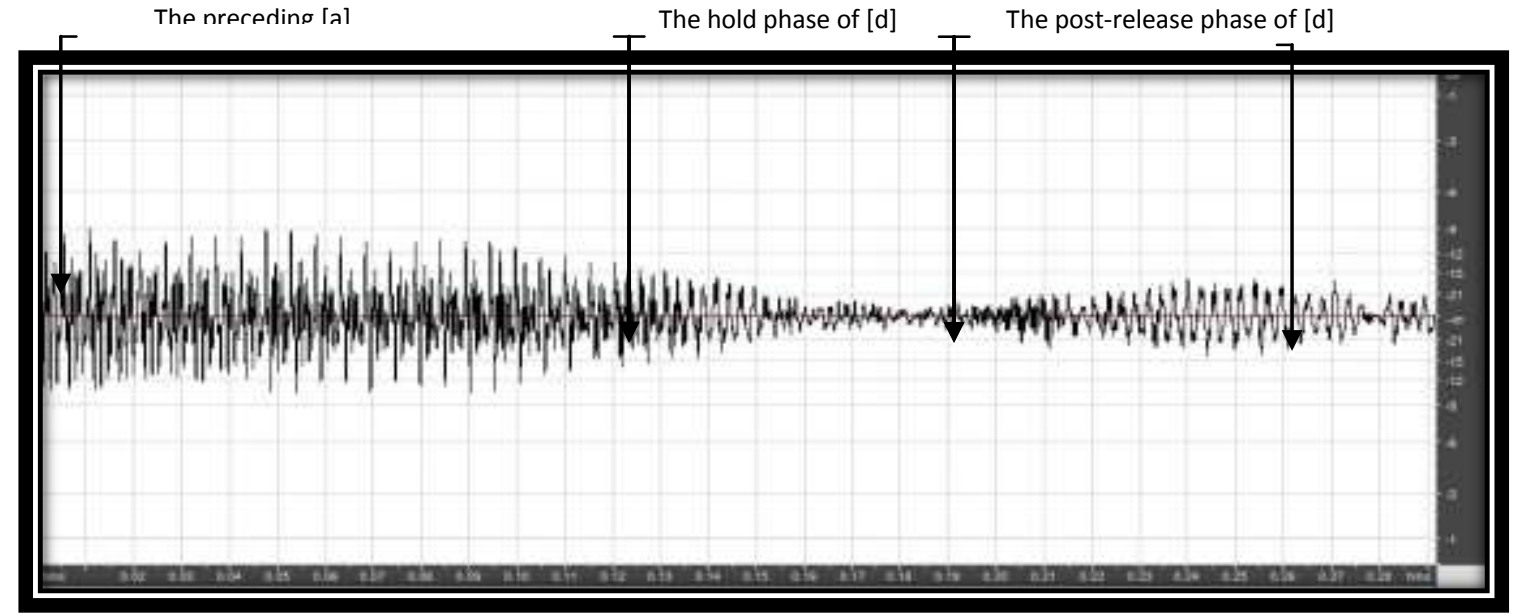

Figure 4: Waveform ofthe preceding [a] and the sound accompanying [d] in ['kabad?]for Al-Manshāwiyy

\subsubsection{Abdul-Hādil-Kanākiriyy}

In Al-Kanākiriyy'sperformance, analysis of the post-release phase of the qalqala sounds [q, t, b, dz, d] in word-medial position shows that the sounds accompanying [q], [t], [b], [d] and [d] have amplitudes of $+2 \mathrm{~dB},+1 \mathrm{~dB},+6 \mathrm{~dB},+3 \mathrm{~dB}$ and $+1 \mathrm{~dB}$, respectively(see Figure 5).

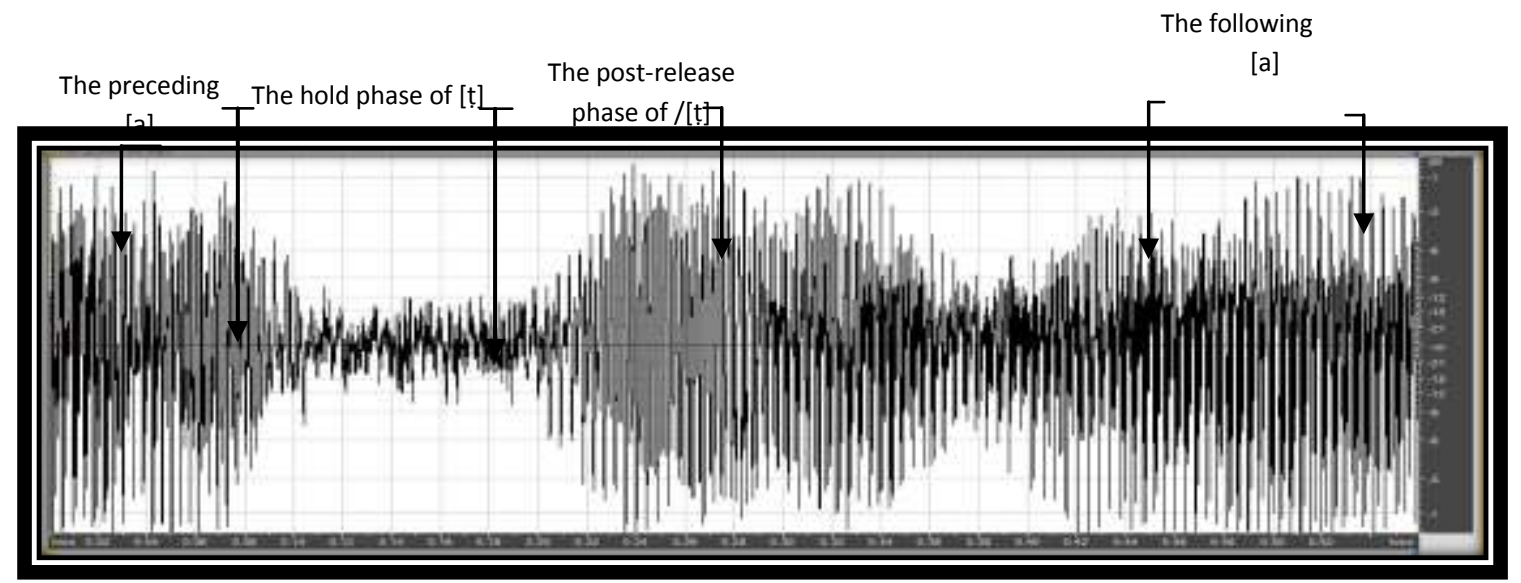

Figure 5: Waveform of the preceding [a], the sound accompanying [t] and the following [a] in [?at?'Yamahum] for AlKanākiriyy.

In word-final position, the sounds accompanying [q], [t], [b], [d]], [d] and the geminated [q] have amplitudes of $+4 \mathrm{~dB},+12 \mathrm{~dB},+5 \mathrm{~dB},+3 \mathrm{~dB},+7 \mathrm{~dB}$ and $+8 \mathrm{~dB}$, respectively (see Figure 6 ).

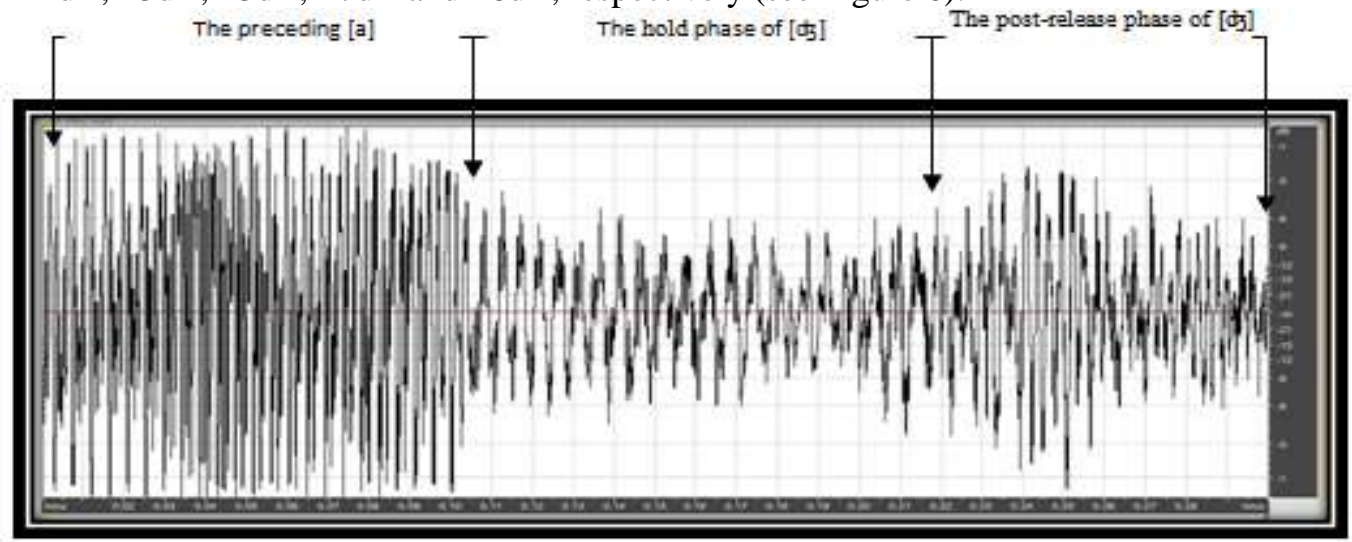

Figure 6: Waveform ofthe preceding [a] and the sound accompanying [d]] in ['haradł?] for Al-Kanākiriyy. 


\subsubsection{Ni'mat Al-Hassān}

In Al-Hassān's performance, analysis of the post-release phase of the qalqala sounds [q, t, b, dz, d] in wordmedial position shows that the sounds accompanying [q], [t], [b], [d] and [d]have amplitudes of $+4 \mathrm{~dB},+4 \mathrm{~dB},+8 \mathrm{~dB}$, $+6 \mathrm{~dB}$ and $+4 \mathrm{~dB}$, respectively (see Figure 7).

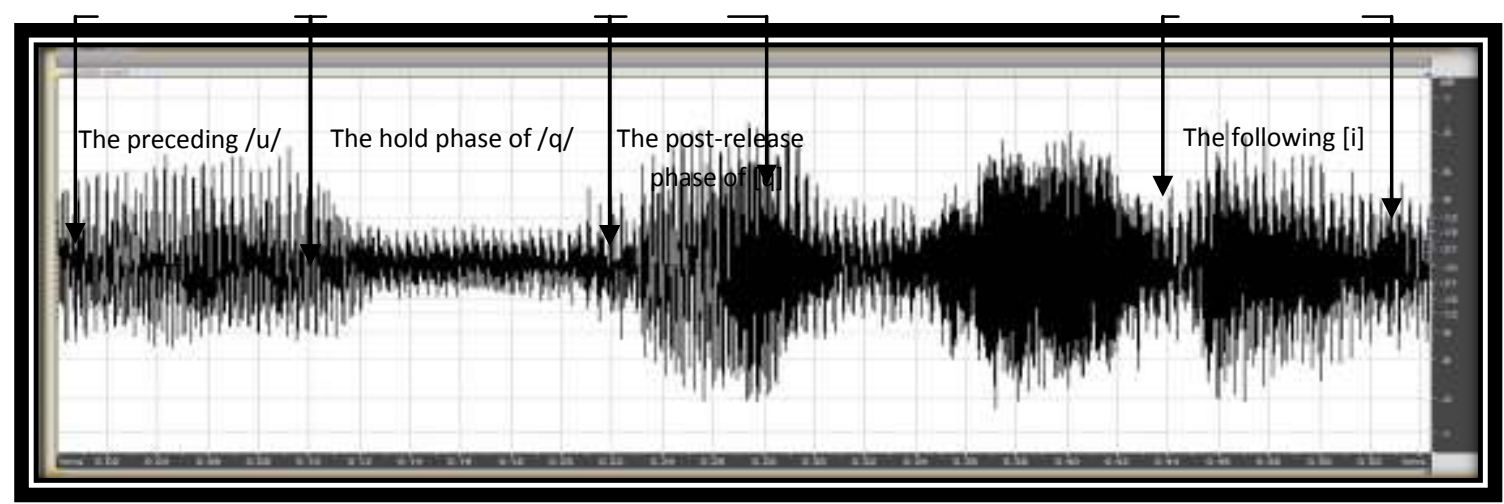

Figure 7: Waveformof the preceding [u], the sound accompanying [q] andthe following [i] in ['Puq?simu] for AlHassān.

In word-final position, the sounds accompanying [q], [t],[b], [d]], [d] and the geminated [q] have amplitudes of $+5 \mathrm{~dB},+4 \mathrm{~dB},+9 \mathrm{~dB},+7 \mathrm{~dB},+12 \mathrm{~dB}$ and $+2 \mathrm{~dB}$, respectively (see Figure 8 ).

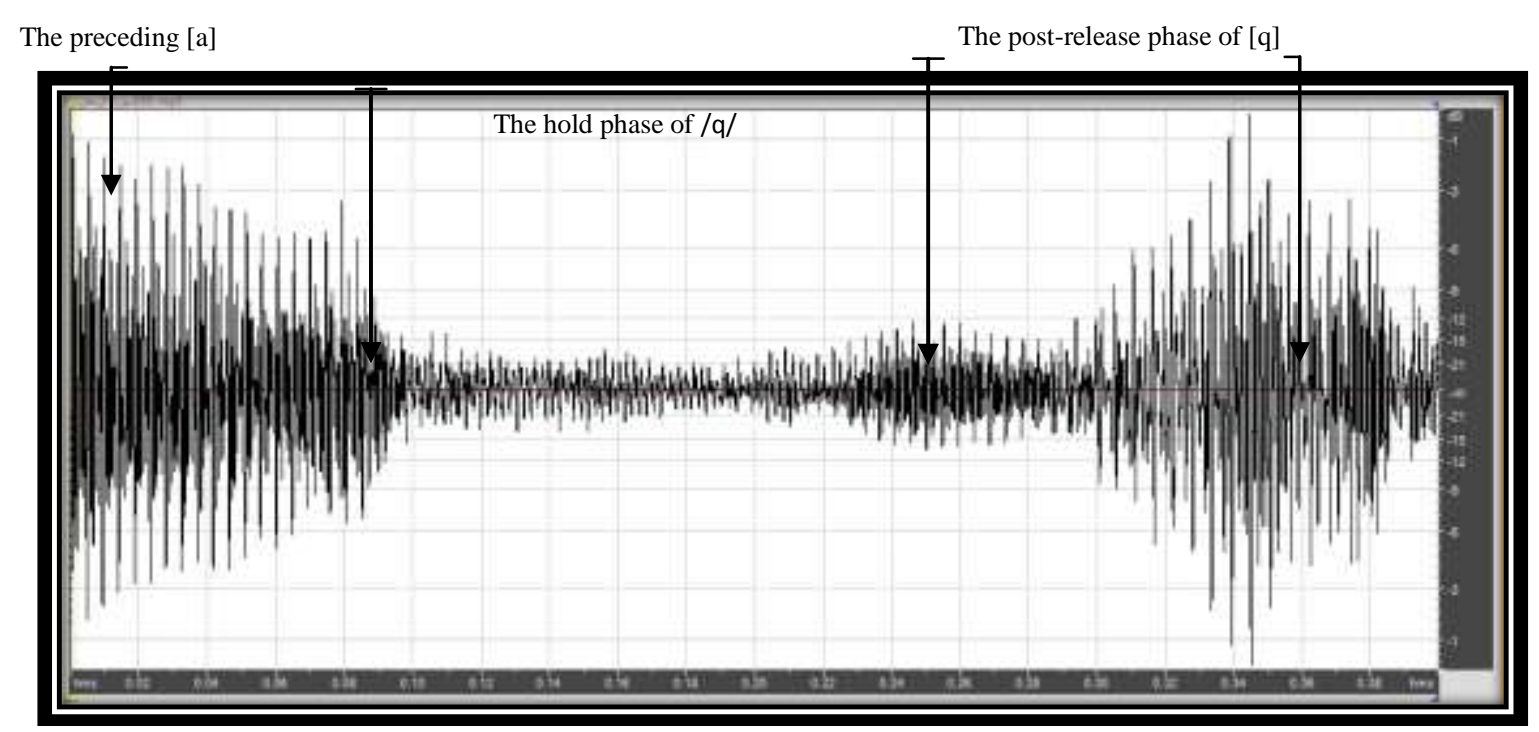

Figure 8: Waveform of the preceding [a] and the sound accompanying [q] in [?is'tab?raq?] for Al-Hassān.

\subsection{Formant Frequency Analysis}

Ladefoged (1993: 162) writes:

"Frequency is...the number of complete repetitions (cycles) of variations in air pressure occurring in a second. The unit of frequency measurement is the Hertz, usually abbreviated as Hz. If the vocal cords make 220 complete opening and closing movements in a second, we say that the frequency of the sound is $220 \mathrm{~Hz}$ ".

Al-Ghāmidiyy (2000: 105) defines frequency as the number of vibrations in one second, measured by Hertz. Thus, the formant frequencies F1 and F2 of the sound accompanying the qalqala sound has been measured to arrive at the quality of this sound and then to compare it with the preceding and following vowels in word-medial position and with the preceding vowel in word-final position.

In word-medial position, analysis of the four reciters' performance of the qalqala sounds shows that F1 and F2 of the preceding [u],the sound accompanying [q] and the following [i] in ['?uq?simu] are as follows:

Al-Ghāmidiyy: $260 \mathrm{~Hz}$ and $500 \mathrm{~Hz}, 280 \mathrm{~Hz}$ and $510 \mathrm{~Hz}$, and $260 \mathrm{~Hz}$ and $555 \mathrm{~Hz}$, respectively; hence ['?uqusimu]. 
Al-Manshāwiyy: $220 \mathrm{~Hz}$ and $432 \mathrm{~Hz}, 189 \mathrm{~Hz}$ and $394 \mathrm{~Hz}$, and $200 \mathrm{~Hz}$ and $400 \mathrm{~Hz}$, respectively; hence ['Puqəsimu] since $\mathrm{F} 1$ and $\mathrm{F} 2$ of [ə] in ['dzepədi] ${ }^{(5)}$ are around $187 \mathrm{~Hz}$ and $390 \mathrm{~Hz}$.

Al-Kanākiriyy: $260 \mathrm{~Hz}$ and $516 \mathrm{~Hz}, 240 \mathrm{~Hz}$ and $470 \mathrm{~Hz}$, and $270 \mathrm{~Hz}$ and $516 \mathrm{~Hz}$, respectively; hence['?uqasimu].

Al-Hassān: $253 \mathrm{~Hz}$ and $555 \mathrm{~Hz}, 225 \mathrm{~Hz}$ and $555 \mathrm{~Hz}$, and $280 \mathrm{~Hz}$ and $570 \mathrm{~Hz}$, respectively;hence ['?uqusimu].

In [?at?'Samahum], F1and F2 of the preceding [a],the sound accompanying [t] andthe following [a] are as follows:

Al-Ghāmidiyy: $270 \mathrm{~Hz}$ and $510 \mathrm{~Hz}, 270 \mathrm{~Hz}$ and $520 \mathrm{~Hz}$, and $270 \mathrm{~Hz}$ and $520 \mathrm{~Hz}$, respectively; hence[Pata' 'Yamahum].

Al-Manshāwiyy: $225 \mathrm{~Hz}$ and $430 \mathrm{~Hz}, 195 \mathrm{~Hz}$ and $370 \mathrm{~Hz}$, and $215 \mathrm{~Hz}$ and $400 \mathrm{~Hz}$, respectively; hence [?aţ'Yamahum] since F1 and F2 of [ə] in ['dzepədi] are around $187 \mathrm{~Hz}$ and $390 \mathrm{~Hz}$.

Al-Kanākiriyy: $272 \mathrm{~Hz}$ and $545 \mathrm{~Hz}, 256 \mathrm{~Hz}$ and $495 \mathrm{~Hz}$, and $256 \mathrm{~Hz}$ and $495 \mathrm{~Hz}$, respectively;hence [?ata' 'amahum].

Al-Hassān: $220 \mathrm{~Hz}$ and $410 \mathrm{~Hz}, 195 \mathrm{~Hz}$ and $400 \mathrm{~Hz}$, and $220 \mathrm{~Hz}$ and $417 \mathrm{~Hz}$, respectively;hence [?aţ' ${ }^{\prime}$ 'amahum] since F1 and $\mathrm{F} 2$ of [ə] in ['dzepədi] are around $187 \mathrm{~Hz}$ and $390 \mathrm{~Hz}$.

In ['șab?ri], F1 and F2 of the preceding [a], the sound accompanying [b], and the following [i] are as follows:

Al-Ghāmidiyy: $260 \mathrm{~Hz}$ and $540 \mathrm{~Hz}, 260 \mathrm{~Hz}$ and $530 \mathrm{~Hz}$, and $230 \mathrm{~Hz}$ and $450 \mathrm{~Hz}$, respectively;hence['ṣabari].

Al-Manshāwiyy: $220 \mathrm{~Hz}$ and $440 \mathrm{~Hz}, 190 \mathrm{~Hz}$ and $380 \mathrm{~Hz}$, and $200 \mathrm{~Hz}$ and $400 \mathrm{~Hz}$, respectively; hence['șabəri] since F1 and F2 of [ə] in word-medial position in ['vent $\left.\int 2 r ə\right]$ are around $165 \mathrm{~Hz}$ and $360 \mathrm{~Hz}$.

Al-Kanākiriyy: $208 \mathrm{~Hz}$ and $416 \mathrm{~Hz}, 185 \mathrm{~Hz}$ and $380 \mathrm{~Hz}$, and $220 \mathrm{~Hz}$ and $425 \mathrm{~Hz}$, respectively; hence ['ṣabəri] since F1 and F2 of [ə] in ['dzepodi] are around $187 \mathrm{~Hz}$ and $390 \mathrm{~Hz}$.

Al-Hassān: $232 \mathrm{~Hz}$ and $487 \mathrm{~Hz}, 232 \mathrm{~Hz}$ and $450 \mathrm{~Hz}$ and $215 \mathrm{~Hz}$ and $415 \mathrm{~Hz}$ recnertivelv

In ['jadz? Yal], F1 and F2 of the preceding [a], the sound accompanying [d]], and the following [a] are as follows:

Al-Ghāmidiyy: $250 \mathrm{~Hz}$ and $500 \mathrm{~Hz}, 250 \mathrm{~Hz}$ and $500 \mathrm{~Hz}$, and $240 \mathrm{~Hz}$ and $475 \mathrm{~Hz}$, respectively; hence ['jadzaSal].

Al-Manshāwiyy: $235 \mathrm{~Hz}$ and $472 \mathrm{~Hz}, 235 \mathrm{~Hz}$ and $472 \mathrm{~Hz}$, and $235 \mathrm{~Hz}$ and $472 \mathrm{~Hz}$, respectively;hence ['jadzaSal].

Al-Kanākiriyy: $235 \mathrm{~Hz}$ and $470 \mathrm{~Hz}, 190 \mathrm{~Hz}$ and $390 \mathrm{~Hz}$, and $235 \mathrm{~Hz}$ and $470 \mathrm{~Hz}$, respectively; hence['jadzəSal] since F1 and F2 of [ə] in ['dzepodi] are around $187 \mathrm{~Hz}$ and $390 \mathrm{~Hz}$.

Al-Hassān: $274 \mathrm{~Hz}$ and $540 \mathrm{~Hz}, 274 \mathrm{~Hz}$ and $540 \mathrm{~Hz}$, and $274 \mathrm{~Hz}$ and $540 \mathrm{~Hz}$, respectively;hence ['jadzaSal].

In ['sad?rak], F1 and F2 of the preceding [a], the sound accompanying [d], and the following [a] are as follows:

Al-Ghāmidiyy: $260 \mathrm{~Hz}$ and $500 \mathrm{~Hz}, 232 \mathrm{~Hz}$ and $450 \mathrm{~Hz}$, and $232 \mathrm{~Hz}$ and $450 \mathrm{~Hz}$, respectively; hence ['ṣadarak] (see Figure 9).

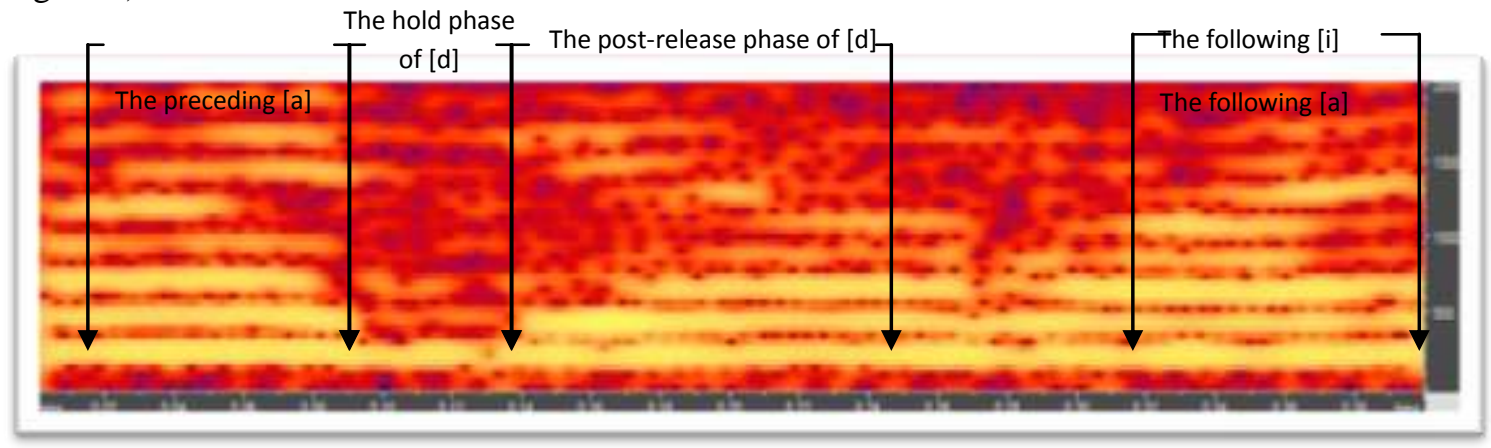

Figure 9: F1 and F2 of the preceding [a], the sound accompanying [d] and the following [a] in ['ṣadarak] for AlGhāmidiyy.

The preceding The hold phase

[a] of [b] The post-release phase of [b]

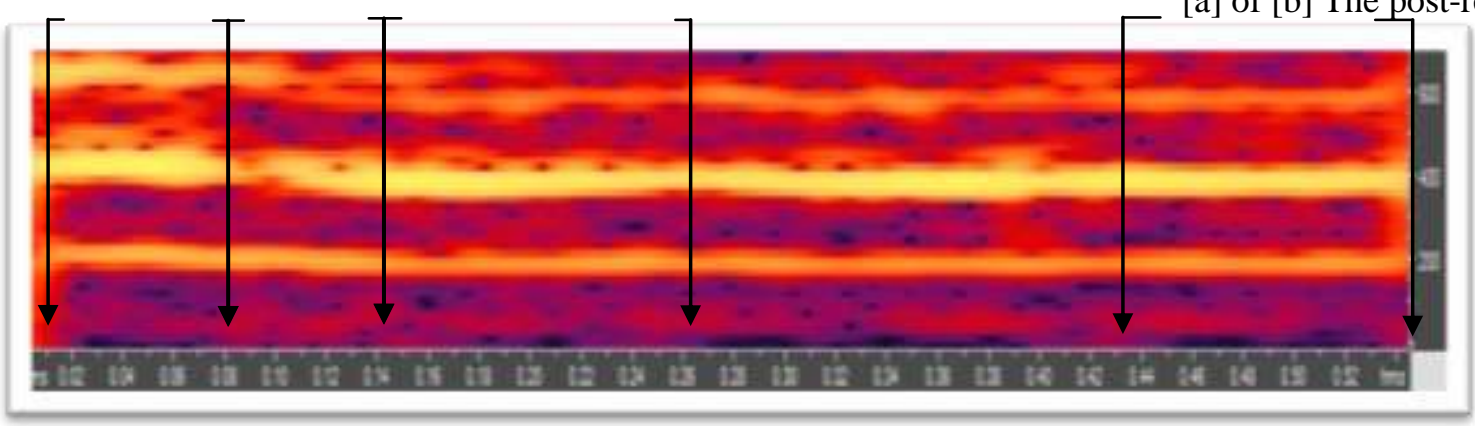

Figure 10: F1 and F2 of the preceding [a], the sound accompanying [b] and the following [i] in ['șabəri] for AlManshāwiyy.

(5) The Recorded materials for the schwa have been taken from Exercise 1 of Tape Unit 9 in Roach (1983: 176f). 
Al-Kanākiriyy: $280 \mathrm{~Hz}$ and $530 \mathrm{~Hz}, 235 \mathrm{~Hz}$ and $487 \mathrm{~Hz}$, and $235 \mathrm{~Hz}$ and $487 \mathrm{~Hz}$, respectively;hence['ṣadarak] (see Figure 11).

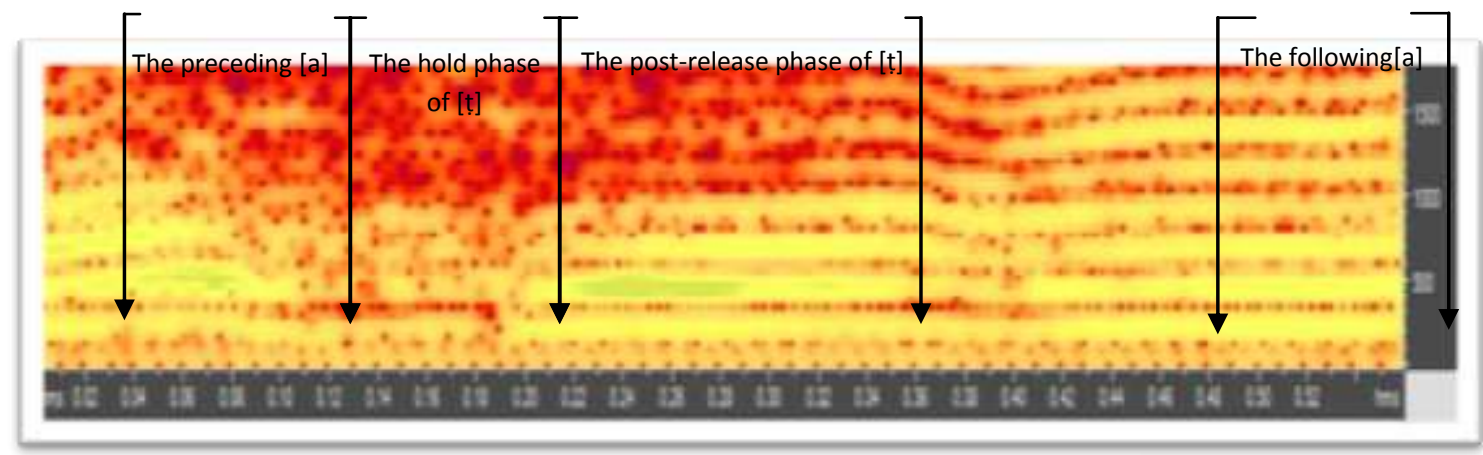

Figure11: F1 and F2 of the preceding [a], the sound accompanying [t] and the following [a] in [?ata'Yamahum] for AlKanākiriyy.

Al-Hassān: 295Hz and 590Hz, 285Hz and 590Hz, and 264Hz and 494Hz, respectively; hence ['ṣadarak] (see Figure 12).

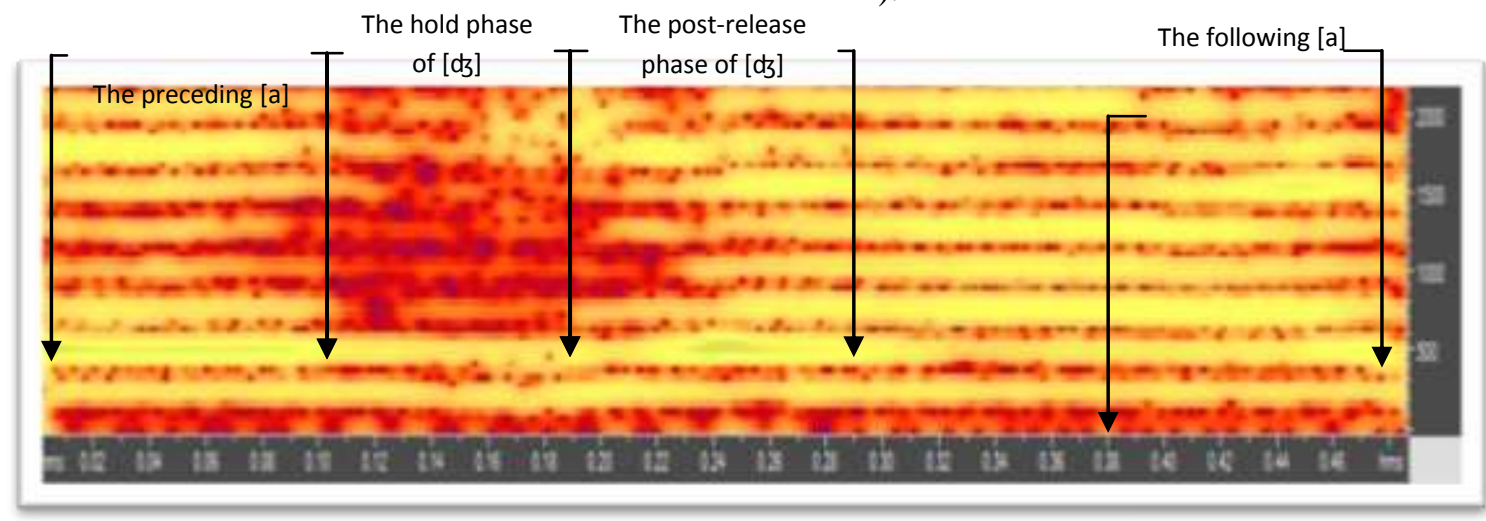

Figure 12: F1 and F2 of the preceding [a], the sound accompanying [d]] and the following [a] in ['jadzaSal] for AlHassān.

In word-final position, F1 and F2 of the preceding [a] in [?is'tab?raq?] and of the sound accompanying [q] are as follows:

Al-Ghāmidiyy:230Hz and $430 \mathrm{~Hz}$, and $190 \mathrm{~Hz}$ and $370 \mathrm{~Hz}$, respectively; hence [Pis'tabəraqə] since $\mathrm{F} 1$ and $\mathrm{F} 2$ of [ə] in ['ventfərə] in word-final position are around $170 \mathrm{~Hz}$ and $365 \mathrm{~Hz}$.

Al-Manshāwiyy: $230 \mathrm{~Hz}$ and $450 \mathrm{~Hz}$, and $195 \mathrm{~Hz}$ and $395 \mathrm{~Hz}$, respectively; hence [?is'tabəraqə] sinceF1 and $\mathrm{F} 2$ of [ə] in ['neit $\int$ ] are around $174 \mathrm{~Hz}$ and $364 \mathrm{~Hz}$.

Al-Kanākiriyy: $250 \mathrm{~Hz}$ and $520 \mathrm{~Hz}$, and $168 \mathrm{~Hz}$ and $370 \mathrm{~Hz}$, respectively; hence [?is'tabəraqə] since F1 and F2 of [ə] in ['neit $\left.\int 2\right]$ are around $174 \mathrm{~Hz}$ and $364 \mathrm{~Hz}$.

Al-Hassān: $240 \mathrm{~Hz}$ and $420 \mathrm{~Hz}$, and $190 \mathrm{~Hz}$ and $360 \mathrm{~Hz}$, respectively; hence [?is'tabəraqə] sinceF1 and $\mathrm{F} 2$ of [ə] in ['seIvjə] are around $190 \mathrm{~Hz}$ and $360 \mathrm{~Hz}$.

In [lu:t?], F1 and F2 of the preceding [u:]and the sound accompanying [t] are as follows:

Al-Ghāmidiyy: $240 \mathrm{~Hz}$ and $480 \mathrm{~Hz}$, and $160 \mathrm{~Hz}$ and $380 \mathrm{~Hz}$, respectively; hence [lu:ț] since F1 and F2 of [ə] in ['longə]are around $167 \mathrm{~Hz}$ and $355 \mathrm{~Hz}$.

AL-Manshāwiyy: $230 \mathrm{~Hz}$ and $470 \mathrm{~Hz}$, and $176 \mathrm{~Hz}$ and $387 \mathrm{~Hz}$, respectively; hence [lu:ț] since F1 and F2 of [ə] in ['nert $\int$ ] are around $174 \mathrm{~Hz}$ and $364 \mathrm{~Hz}$.

Al-Kanākiriyy: $230 \mathrm{~Hz}$ and $473 \mathrm{~Hz}$, and $160 \mathrm{~Hz}$ and $380 \mathrm{~Hz}$, respectively; hence [lu:ța] sinceF1 and F2 of [ə] in ['neit $\left.\int ə\right]$ are around $174 \mathrm{~Hz}$ and $364 \mathrm{~Hz}$.

Al-Hassān:216Hz and 444Hz, and 184Hz and 368Hz, respectively; hence [lu:țə] sinceF1 and F2 of[ə] in ['nert $ə$ ] are around $174 \mathrm{~Hz}$ and $364 \mathrm{~Hz}$.

In ['waqab?], F1 and F2 of the preceding [a] and the sound accompanying [b] are as follows:

Al-Ghāmidiyy: $250 \mathrm{~Hz}$ and $470 \mathrm{~Hz}$, and $208 \mathrm{~Hz}$ and $407 \mathrm{~Hz}$, respectively;hence ['waqabə] since $\mathrm{F} 1$ and $\mathrm{F} 2$ of [ə] in ['servjə] are around $190 \mathrm{~Hz}$ and $395 \mathrm{~Hz}$. 
Al-Manshāwiyy: $202 \mathrm{~Hz}$ and $404 \mathrm{~Hz}$, and $177 \mathrm{~Hz}$ and $370 \mathrm{~Hz}$, respectively; hence ['waqabə] since [ə] in ['neit $\int$ ] whose $\mathrm{F} 1$ and $\mathrm{F} 2$ are around $174 \mathrm{~Hz}$ and $364 \mathrm{~Hz}$, respectively.

Al-Kanākiriyy: $240 \mathrm{~Hz}$ and $450 \mathrm{~Hz}$ and $185 \mathrm{~Hz}$ and $380 \mathrm{~Hz}$, respectively; hence ['waqabə] sinceF1 and $\mathrm{F} 2$ of [ə] in ['neit $\left.\int ə\right]$ are around $174 \mathrm{~Hz}$ and $364 \mathrm{~Hz}$.

Al-Hassān: $282 \mathrm{~Hz}$ and $550 \mathrm{~Hz}$ and $282 \mathrm{~Hz}$ and $525 \mathrm{~Hz}$, respectively; hence ['waqaba].

In ['harads?], F1 and F2 of the preceding [a] and the sound accompanying [d] are as follows:

Al-Ghāmidiyy: $230 \mathrm{~Hz}$ and $440 \mathrm{~Hz}$, and $180 \mathrm{~Hz}$ and $320 \mathrm{~Hz}$, respectively; hence['haradzə] since $\mathrm{F} 1$ and $\mathrm{F} 2$ of [ə] in ['kılo]are around $130 \mathrm{~Hz}$ and $300 \mathrm{~Hz}$.

Al-Manshāwiyy: $210 \mathrm{~Hz}$ and $410 \mathrm{~Hz}$, and $185 \mathrm{~Hz}$ and $370 \mathrm{~Hz}$, respectively; hence ['haradzə] since F1 and F2 of [ə] in ['neit $\int$ ə] are around $174 \mathrm{~Hz}$ and $364 \mathrm{~Hz}$.

Al-Kanākiriyy: $245 \mathrm{~Hz}$ and $470 \mathrm{~Hz}$, and $195 \mathrm{~Hz}$ and $375 \mathrm{~Hz}$, respectively; hence ['haradzə] since F1 and F2 of [ə] in ['neit $\int$ ] are around $174 \mathrm{~Hz}$ and $364 \mathrm{~Hz}$.

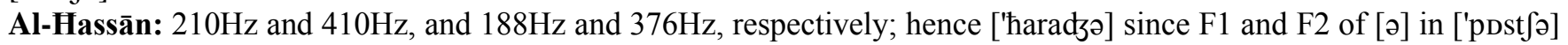
are around $167 \mathrm{~Hz}$ and $375 \mathrm{~Hz}$.

In ['kabad?], F1 and F2 of the preceding [a]and the sound accompanying [d]are as follows:

Al-Ghāmidiyy: $206 \mathrm{~Hz}$ and $430 \mathrm{~Hz}$, and $206 \mathrm{~Hz}$ and $430 \mathrm{~Hz}$, respectively; hence['kabada].

Al-Manshāwiyy: $220 \mathrm{~Hz}$ and $400 \mathrm{~Hz}$, and $184 \mathrm{~Hz}$ and $360 \mathrm{~Hz}$, respectively; hence ['kabadə]sinceF1 and $\mathrm{F} 2$ of [ə] in ['neit $\left.\int 2\right]$ are around $174 \mathrm{~Hz}$ and $364 \mathrm{~Hz}$.

Al-Kanākiriyy: $240 \mathrm{~Hz}$ and $490 \mathrm{~Hz}$ and $182 \mathrm{~Hz}$ and $370 \mathrm{~Hz}$, respectively; hence ['kabadə] sinceF1 and F2 of [ə] in ['neit $\int$ ə] are around $174 \mathrm{~Hz}$ and $364 \mathrm{~Hz}$.

Al-Hassān:238Hz and $477 \mathrm{~Hz}$ and $228 \mathrm{~Hz}$ and $447 \mathrm{~Hz}$, respectively; hence ['kabada].

In the case of the geminated [q] at the end of ['haqq?], F1 and F2 of the preceding [a]and the sound accompanying [q] are as follows:

Al-Ghāmidiyy: $260 \mathrm{~Hz}$ and $478 \mathrm{~Hz}$, and $200 \mathrm{~Hz}$ and $400 \mathrm{~Hz}$, respectively; hence['haqqə] since F1 and F2 of [ə] in ['servjə] are around $190 \mathrm{~Hz}$ and $395 \mathrm{~Hz}$ (see Figure 13).

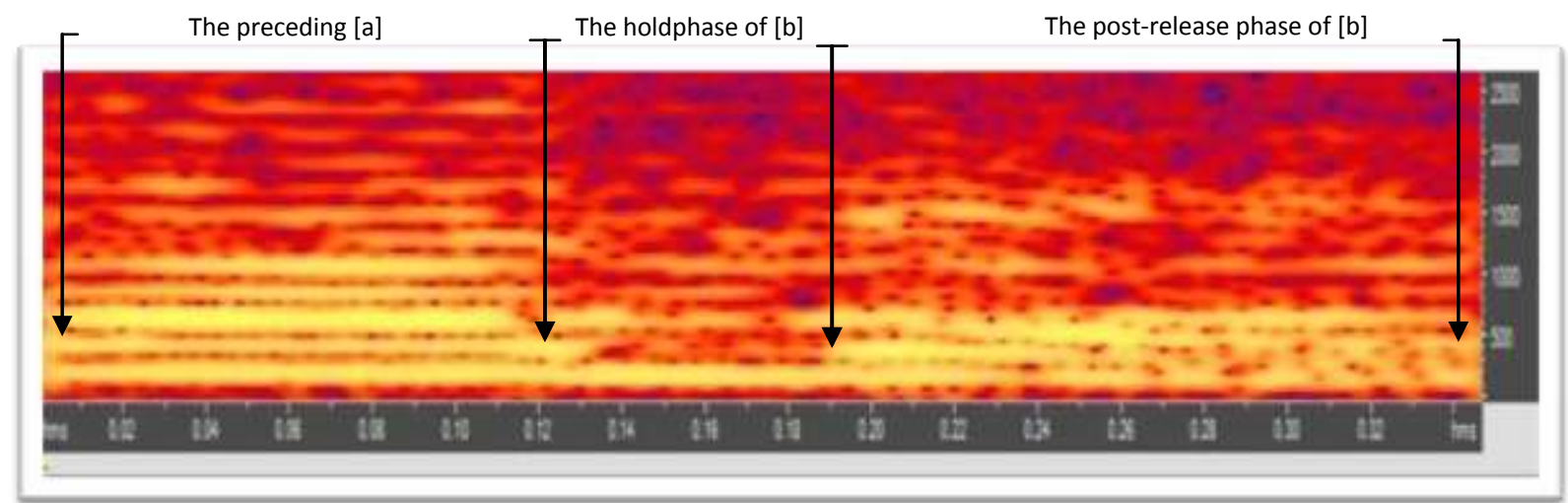

Figure 13: F1 and F2 of the preceding [a] and the sound accompanying [b] in ['waqabə] for Al-Ghāmidiyy.

Al-Manshāwiyy: $212 \mathrm{~Hz}$ and $430 \mathrm{~Hz}$, and $168 \mathrm{~Hz}$ and $340 \mathrm{~Hz}$, respectively; hence ['haqqə] sinceF1 and $\mathrm{F} 2$ of [ə] in ['neit $\int$ ] are around $174 \mathrm{~Hz}$ and $364 \mathrm{~Hz}$ (see Figure 14).

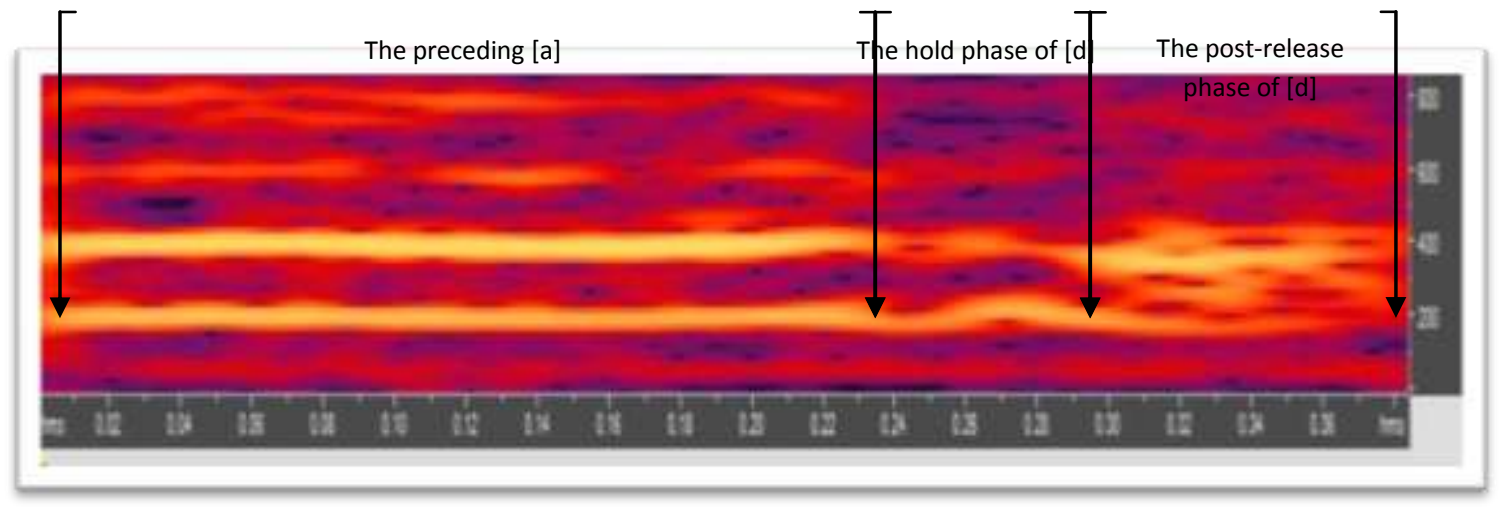

Figure 14: F1 and F2 of the preceding [a] and the sound accompanying [d] in ['kabadə] for Al-Manshāwiyy. 
Al-Kanākiryy:270Hz and 500Hzand $185 \mathrm{~Hz}$ and $385 \mathrm{~Hz}$, respectively;hence['haqqə] since F1 and F2 of [ə] in ['nert $ə$ ] are around $174 \mathrm{~Hz}$ and $364 \mathrm{~Hz}($ see Figure 15$)$.

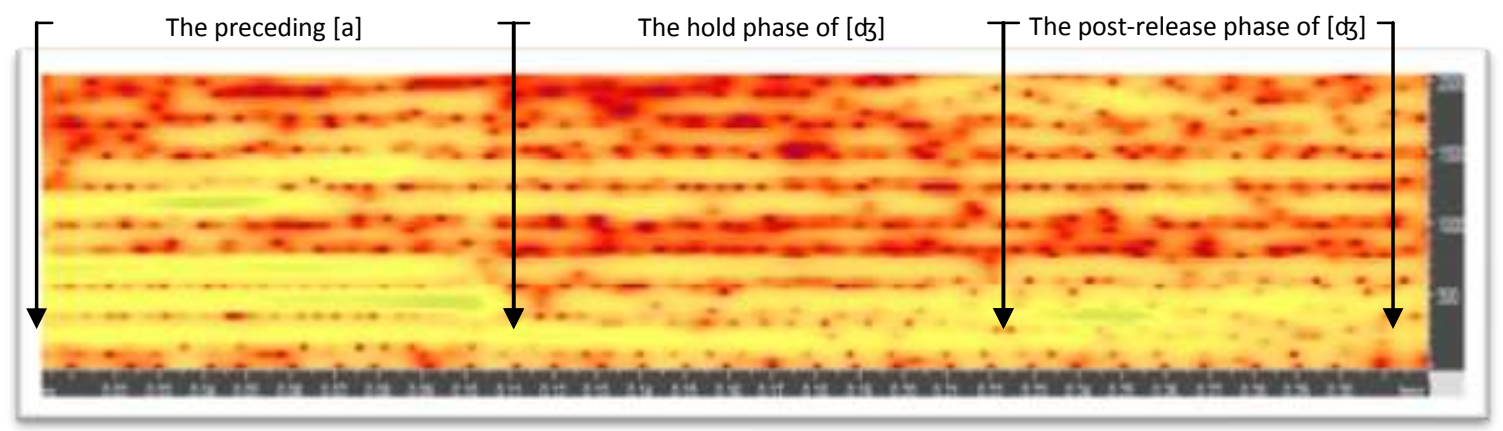

and F2 of the preceding [a] and the sound accompanying [d]] in ['haradzə] for Al-Kanākiriyy.

Figure 15: F1

Al-Hassān:270Hz and 520Hz, and 260Hz and 509Hz, respectively; hence ['haqqa] (see Figure 16).

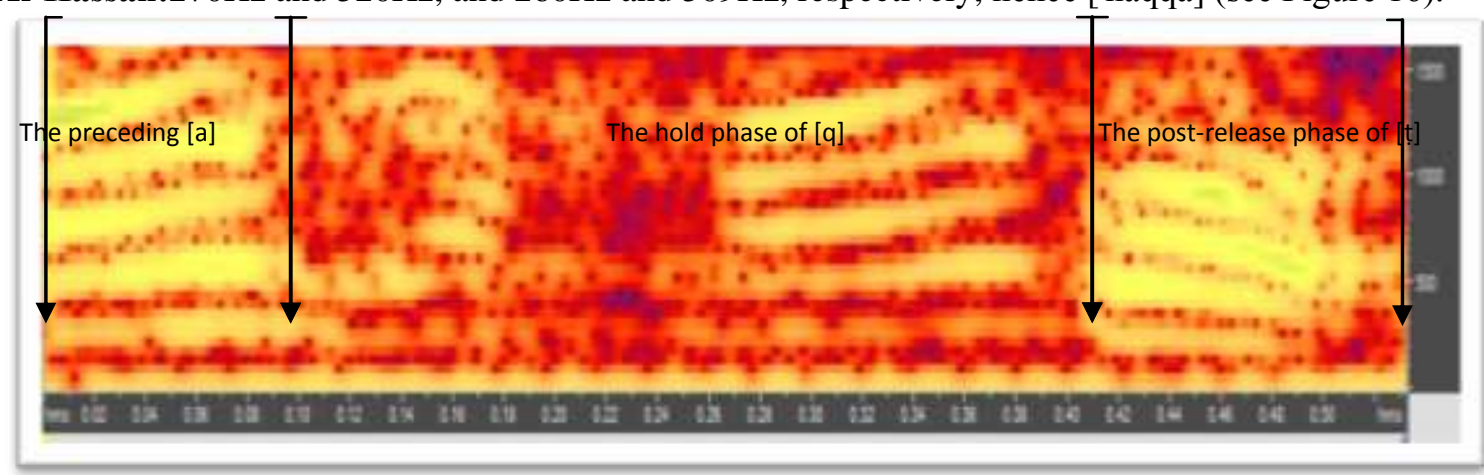

Figure 16: F1 and F2 of the preceding [a] and the sound accompanying the geminated [q] in ['haqqa] for Al-Hassān.

\subsection{Waveform Repetition}

Ladefoged (1996: 49) states that "vowels which continue for a comparatively long time; contain a number of consecutive waves which are almost identical to one another." These waves have different shapes according to vowel quality; so, a difference in the shape of the wave means a difference in the quality of the vowel and "they are heard as different vowels because each has a characteristic wave shape....in each of them the complex pattern repeats itself every one-hundredth of a second" (Ladefoged, 1996: 28). Analysis of the post-release phase of the qalqala sound together with the other vowel in the utterances shows that the sound accompanying the qalqala sound has a waveform which repeats itself every $0.02-0.06 \mathrm{sec}$. This applies to the post-release phase of all the qalqala sounds. For example, in wordmedial position, the waveform of the preceding vowel [a] and the sound accompanying [b] in ['ṣabari] repeats itself every $0.03 \mathrm{sec}$. This means that the sound accompanying $[\mathrm{b}]$ is a vowel similar to the preceding vowel $[\mathrm{a}]$ in waveform repetition (see Figures17 and 18).

Waveform of the preceding [a]
Repetition of the waveform of the preceding [a]
Repetition of the waveform of the preceding [a] 


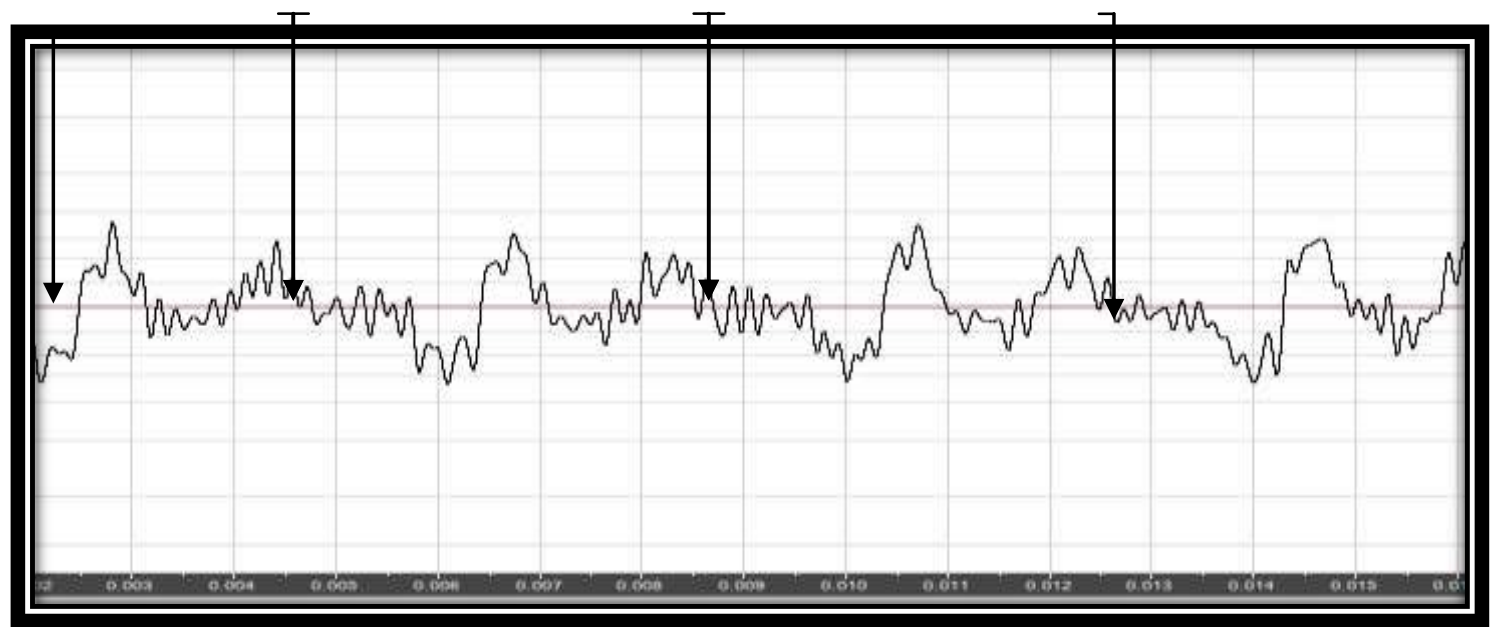

Figure 17: Repetition of the waveform of the preceding vowel [a] in ['ṣabari]every 0.03sec. for Al-Ghāmidiyy.

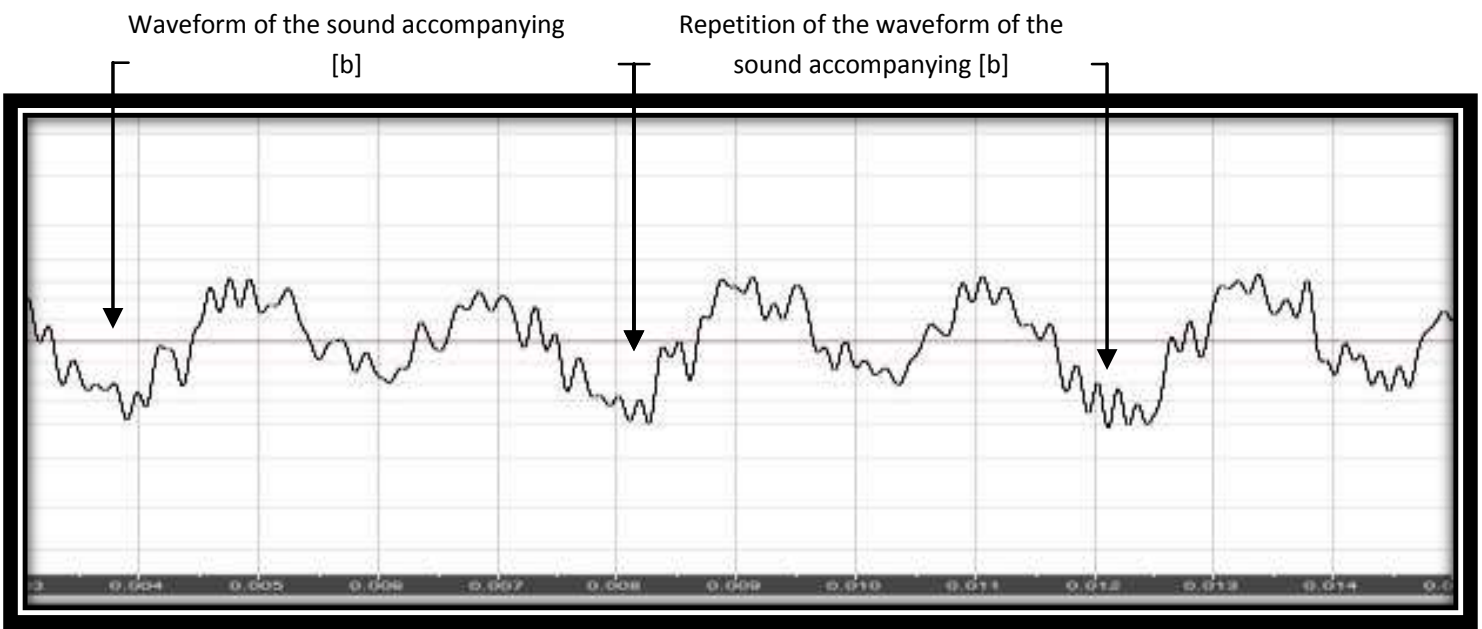

Figure 18: Repetition of the waveform of the sound accompanying [b] in ['ṣabari] every 0.03secfor Al-Ghāmidiyy.

In the articulation of the qalqala sound [d] in ['jadzaSal], the waveform of the preceding [a] and that of the sound accompanying [d] $]$ repeats itself every $0.02 \mathrm{sec}$ (see Figures 19 and 20).

Figure 19: Repetition of the waveform of the preceding [a] in ['jadzaSal] every 0.02sec. for Al-Manshāwiyy.

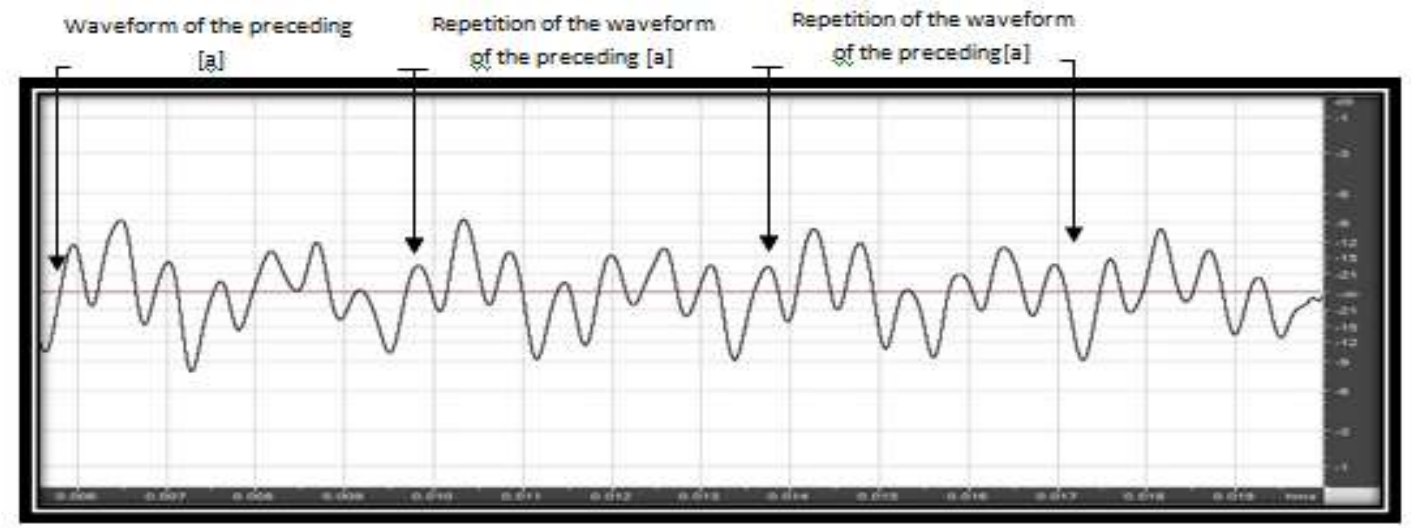




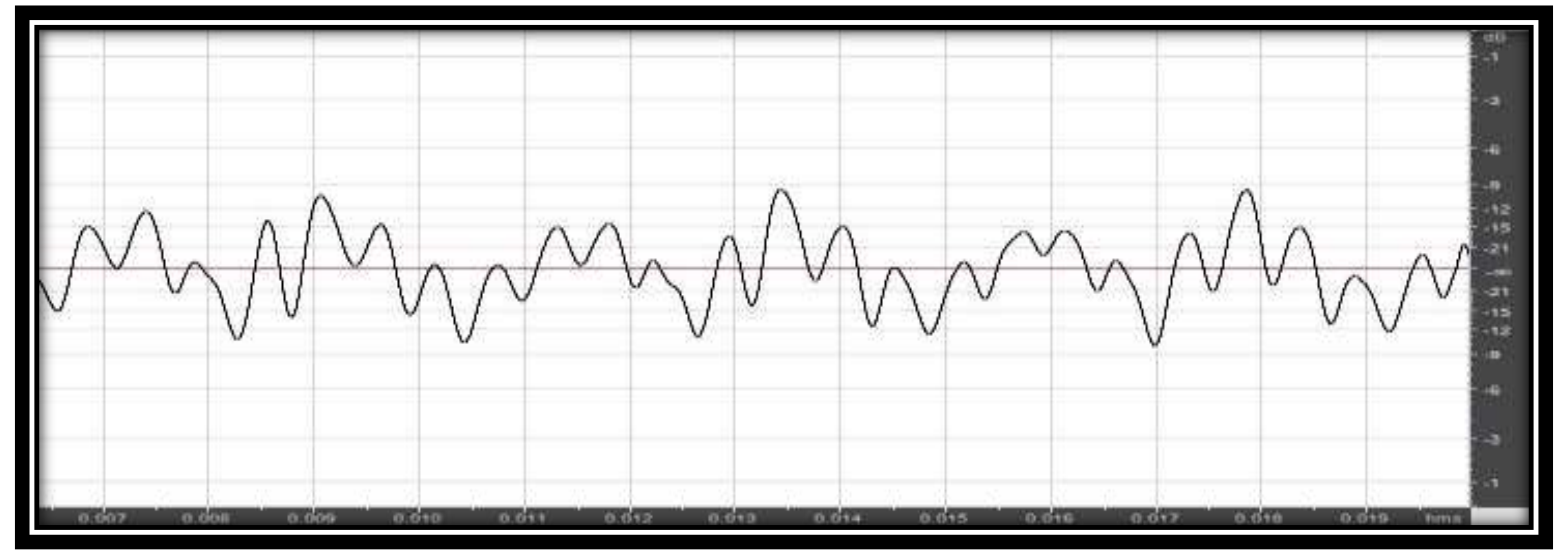

Figure 20: Repetition of the waveform of the sound accompanying [d]] in ['jadzafal] every 0.02sec. for AlManshāwiyy.

In the articulation of the qalqala sound [d] in ['șadarak], the waveform of the preceding [a] and that of the sound accompanying [d] repeat itself every 0.04sec (see Figures 21 and 22).

Waveform of the preceding [a] Repetition of the waveform of the preceding [a]

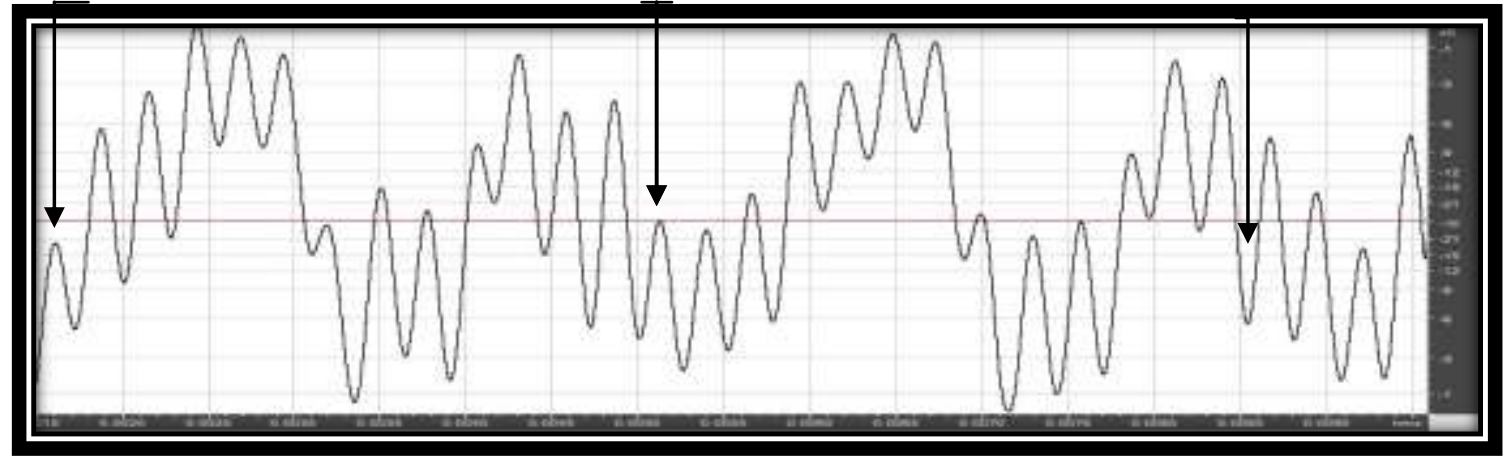

Figure:21: Repetition of the waveform of the preceding [a] in [șadarak] every 0.04secfor Al-Kanākiriyy

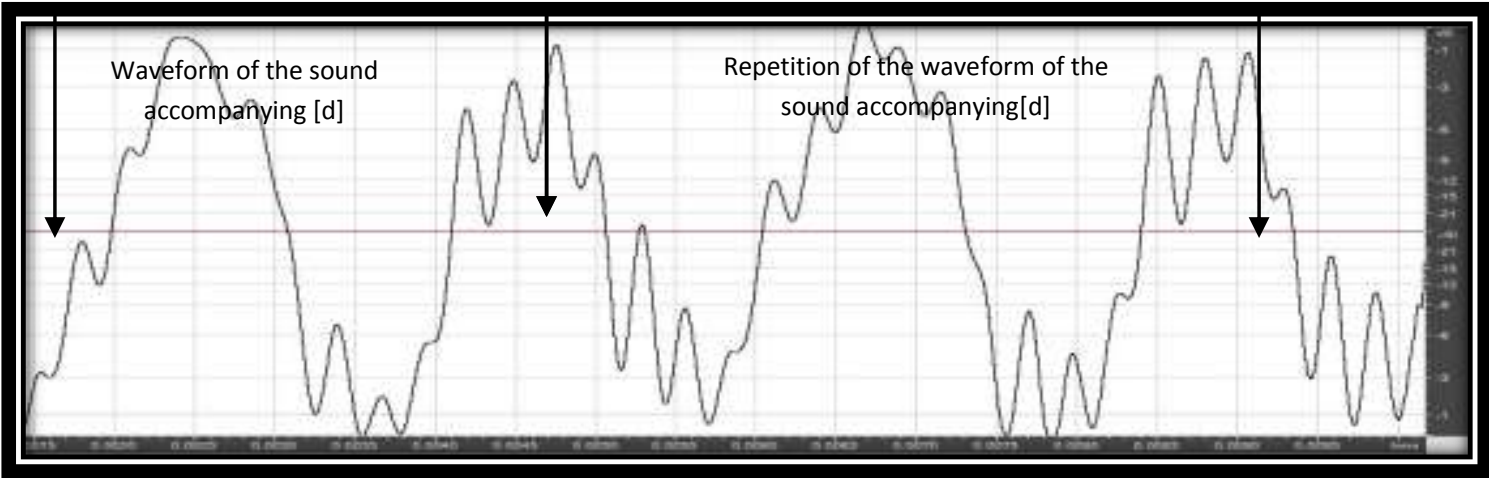

Figure: 22: Repetition of the waveform of the sound accompanying [d] in [șadarak] every 0.04secfor Al-Kanākiriyy.

In the articulation of the qalqala sound [d] in ['?ahadə], the waveform of the preceding [a] and that of the sound accompanying [d] repeats itself every $0.03 \mathrm{sec}$ (see Figures 23 and 24). 


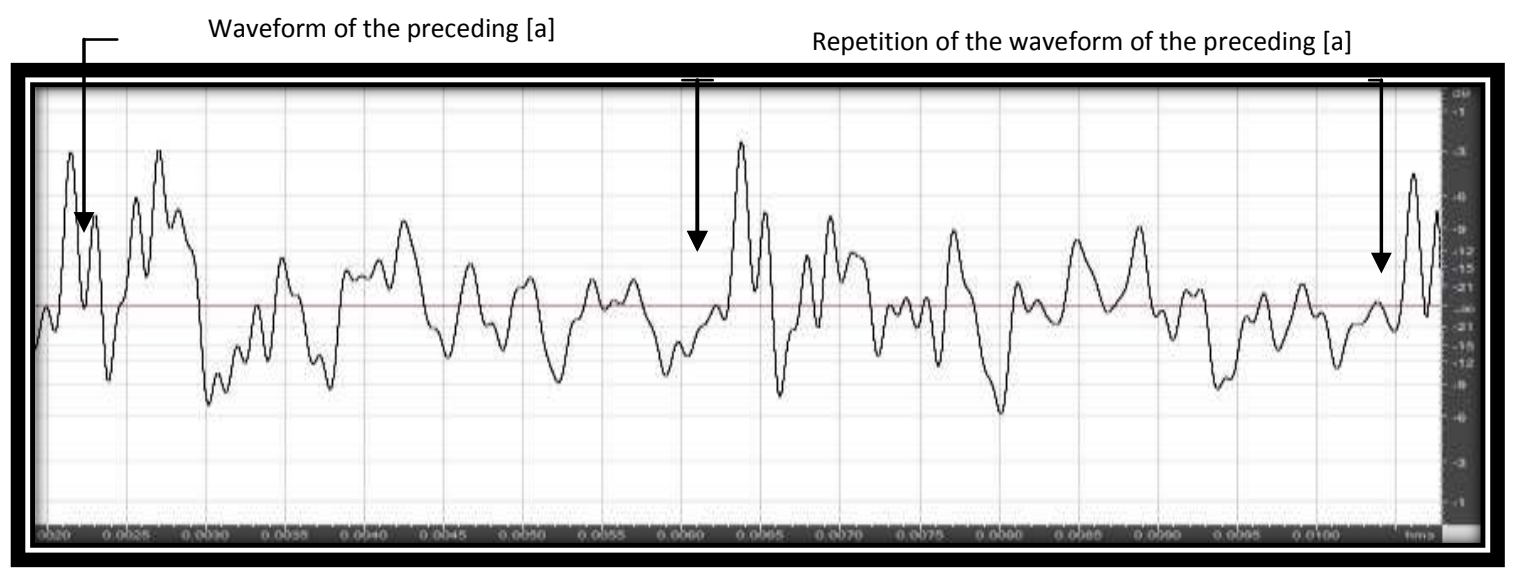

Figure 23: Repetition of the waveform of the preceding [a] in ['?ahadə] every $0.03 \mathrm{sec}$.for Al-Hassān.

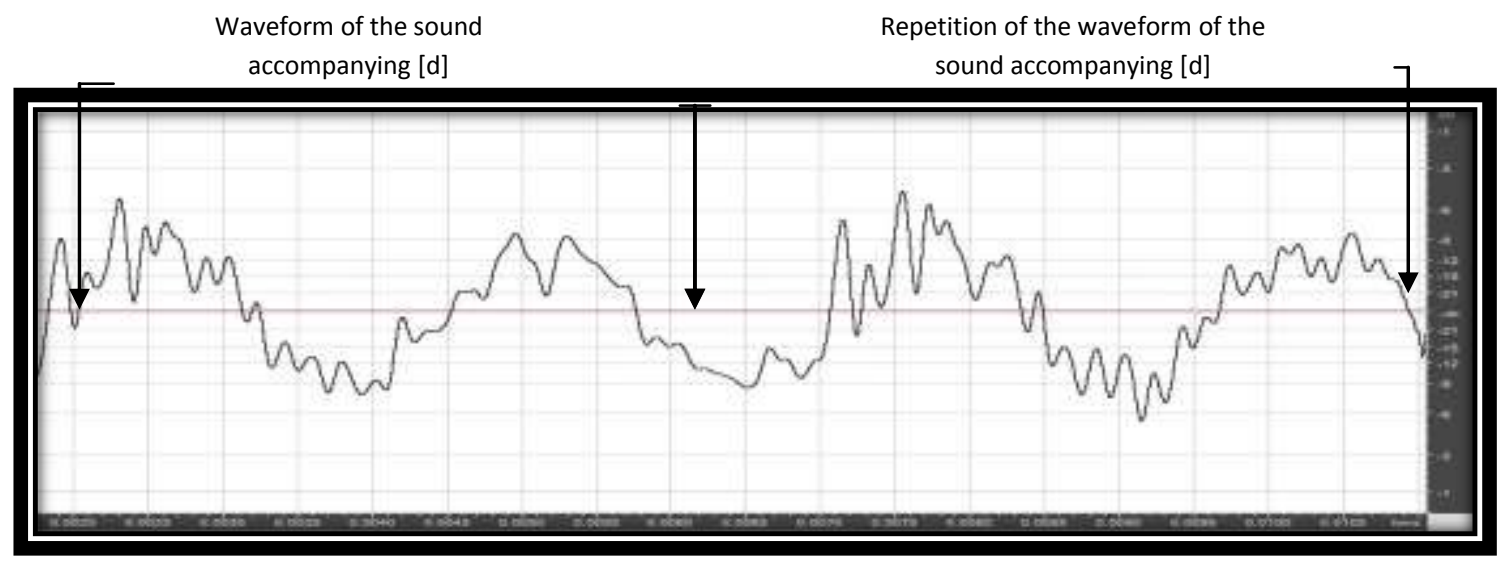

Figure 24: Repetition of the waveform of the sound accompanying [d] in ['Paћadə] every 0.03sec.for Al-Hassān

\section{The Phonological Status of the Sound Accompanying the Qalqala Sounds}

Since the sound accompanying the qalqala sound is a vowel like fatha, dhamma and/or schwa, then it is considered as a phoneme which occurs whenever the qalqala sounds occur. [a] and [u] have long been established as distinctive segments in Arabic, i.e. separate phonemes /a/ and /u/. As regards schwa [ə] which occurs only as a sound realizing the phenomenon of qalqala in reciting Qur'ānic verses, there is a well-established phonological principle: "once a phoneme, always a phoneme", thus the sound accompanying the qalqala sound is a phoneme which can be tested by the "minimal-pair test" as follows:

['ṣabər] "patience" / ['ṣabar] "he showed patience"

['qadər] "dignity" / ['qadar] "destiny"

['badər] "full moon"/ ['badar] "he came unexpectedly"

['naqəạ]] "rescission" / ['naqaḍ] "he refuted"

[li'Padzolihi] "for his sake" / [li?a'dzalihi] "for his moment of death"

['qațəY] "assertion" / ['qațaY] "he asserted"

['fadzər] "dawn" / ['fadzar] "he acted immorally"

From the above minimal-pair test, we may conclude that [ə] functions in Qur'ānic recitation as a distinctive segment, i.e. a separate phoneme /o/, just like the other vowels accompanying the qalqala sounds, i.e. /a/ and /u/.

\section{Results and Discussion}

The results of the acoustic analysis of the qalqala sounds in terms of amplitude, formant frequency and waveform repetition are as follows: 


\subsection{Amplitude Analysis}

When measuring the amplitude of the sound accompanying the qalqalasound (the post-release phase of the qalqala sound), the spectrographic analysis shows that this sound is a vowel since it has intensity like any other vowel in the examined utterances for all the four reciters. However, the value for intensity is different from one reciter to another.

\subsection{Formant Frequency Analysis}

The results of F1 and F2of the sound accompanying the qalqala sound in word-medial position show that this sound is mostly close to [a] in Al-Ghāmidiyy'sperformance.In word-final position, on the other hand, the spectrographic analysis shows that the sound accompanying the qalqala sound is close to [ə].

The spectrographic analysis of Al-Manshāwiyy's performance shows that the sound accompanying the qalqala sound is close to [ə] in word-medial and word-final positions. The results of Al-Kanākiriyy's performance show that the sound accompanying the qalqala sound is close to [a]in word-medial position, whereas it is close to [ə] in word-final position.

Finally, the results of the spectrographic analysis of Al-Hassān's performance show that the sound accompanying the qalqala sound is close to /a/ in word-medial position, whereas in word-final position it is sometimes close to /a/ and sometimes close to $/ \mathrm{\partial} /$.

\subsection{Waveform Repetition}

The results of waveform repetition of the four reciters show that the sound accompanying the qalqala sound is a vowel that has a waveform which repeats itselfevery $0.02-0.06 \mathrm{sec}$ similar to the other vowels in the utterance.

\section{Conclusions}

It may be concluded that the sound accompanying the qalqala sound is a vowel-like articulation since it has intensity; this vowel is,in view of its F1 and F2,mostly close to [ə]. The waveform of the sound accompanying the qalqala sound repeats itself at regular time intervals. It is also concluded that the phenomenon of qalqalais of two levels: minimum and maximum, since there is no real difference between the geminated qalqala sound and its non-geminated counterpart. Because the phenomenon of qalqala is a feature that goes against the natural human tendency for economy of muscular effort, there is no stability among the four reciters' performance of qalqala sounds.

\section{References}

Al-Ghāmidiyy, M. (2000).Aṣ-Ṣawtiyyātul 'Arabiyya (Arabic Phonetics).Ar-Riyādh: King Fahad National Library. Al-Ghawthāniyy, Y.A.(2011). 'Iilmut-Tajwīd: 'AłkāmunNathariyya, MulāhathātunTaṭ̂̄̄qiyya.(Tajwīd Science Theoretical Rulesand Practical Remarks). $10^{\text {th }}$ ed.,Syria: Dārul-Ghawthāniyy for Qur'ānic Studies.

Al-Harbiyy, S.Kh. (2006).'Al-MuthakkiratufīSharhilMuqaddima (The Memorandum on Illustrating the Introduction).Kingdom of Saudi Arabia: Ministry of Education, Training and Arousing Centre.

Arbāwiyy, S.F. (2004). AșwātHurūfilQalqalaBaynalQudāmāwalMuhdathīn (The Sounds of Qalqala between the Old and Contemporary Scholars).Available at: www.ammar-ca.com[farghali[

Bishr, K.M. (2000). 'Ilmul 'Aṣwāt (Phonetics). Egypt: DāruGharīb.

Denny, F. M. (1989)."Qur'ān Recitation: A Tradition of Oral Performance and Transmission".Journal of Oral Tradition, $4: 1,2,5,26$.

Ladefoged, P. (1996). Elements of Acoustic Phonetics. $2^{\text {nd }}$ ed., Chicago: Chicago University Press.

Ladefoged, P. (1993). A Course in Phonetics. ${ }^{\text {rd }}$ ed., Florida:Harcourt Brace Jovanovich.

Nelson, K. (2001). The Art of Reciting the Qur'an. Egypt: Darul-Kutub for Publication. The American University Press.

Roach, P. (1983). English Phonetics and Phonology:A Practical Course.Cambridge: CUP.

Sulaymān, F.A. (1988). Al-Munīrul-JadīdfīAhkāmit-Tajwīd (The New Enlightening on Tajwīd Rules). $1^{\text {st }}$ ed,Egypt: Islamic Research Academy.

Swayyid, A. R. (2011). At-Tajwīdul-Muṣawwar (Pictorial Tajwīd) $1^{\text {st }}$ ed, Syria: Ibnul-Jazriyy Library.

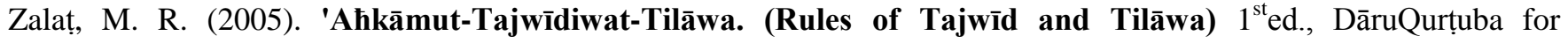
Publication. 